\title{
Persistent N2 disease after neoadjuvant treatment...and now? -The oncologist view
}

\author{
Oliver Gautschi ${ }^{1}$, Fabrizio Minervini ${ }^{2}$, Peter Kestenholz ${ }^{2}$ \\ ${ }^{1}$ University of Berne and Cantonal Hospital of Lucerne, Lucerne, Switzerland; ${ }^{2}$ Thoracic Surgery, Cantonal Hospital of Lucerne, Lucerne, \\ Switzerland \\ Correspondence to: Prof. Dr. med. Oliver Gautschi. University of Berne and Cantonal Hospital of Lucerne, Lucerne, Switzerland. \\ Email: oliver.gautschi@luks.ch.
}

Received: 21 April 2020; Accepted: 15 June 2020; Published: 25 November 2021.

doi: $10.21037 /$ ccts-20-87

View this article at: http://dx.doi.org/10.21037/ccts-20-87

The role of surgery in stage III non-small cell lung cancer (NSCLC) remains a popular topic for controversy sessions during international conferences. Stage III is a wide definition, and includes tumors of various size and extent of lymphatic spread. Modern clinical trials in stage III disease focused on $\mathrm{N} 2$, to narrow the spectrum and increase the impact of clinical trials. Still, N2 includes a wide anatomical spectrum, ranging from single station, to multistation or bulky disease. Many patients have comorbidities that affect tolerance of surgery, radiation and systemic therapy. For these reasons, treatment decisions remain highly individualized, with expertise and multidisciplinary tumor boards required to grant the highest possible quality standards.

What did we learn from the past? Based on pivotal clinical trials in France and Spain, showing the feasibility of neoadjuvant chemotherapy in N2 disease, this approach became popular in Europe in the 1990s. The Swiss Group for Clinical Cancer Research (SAKK) conducted its own trials, using a relatively intense chemotherapy regimen with 3 cycles of cisplatin $100 \mathrm{mg} / \mathrm{m}^{2}$ and docetaxel $85 \mathrm{mg} / \mathrm{m}^{2}$ as a backbone. In the nonrandomized phase II trial SAKK16/96, the overall clinical response rate (ORR) with chemotherapy was $66 \%$, complete pathological remission (pCR) was $19 \%$. Achieving R0-resection and nodal downstaging from N2 to N0-1 was associated with favorable prognosis, with a median overall survival (OS) and event free survival (EFS) of 33 and 14.8 months, respectively (1). The prognostic role of R0-resection and nodal downstaging was confirmed by many other groups in subsequent studies.

The randomized phase III trial SAKK16/00 studied the role of preoperative radiotherapy with $44 \mathrm{~Gy}$ in 22 fractions over 3 weeks in 232 patients with pathologically proven and operable N2-disease, using neoadjuvant chemotherapy in both groups. The rates of R0-resection ( $91 \%$ vs. $81 \%$ ), nodal downstaging (64\% vs. $53 \%)$ and pCR (16\% vs. $12 \%)$ were slightly higher in the chemo-radiotherapy group. However, median EFS was approximately 12 months in both groups, showing no benefit for preoperative sequential chemo-radiotherapy over chemotherapy followed by surgery (2). Recently, the SAKK published a pooled analysis, showing 10 -year OS rate of $29 \%$ in resectable N2 disease (3). Based on these results, in Switzerland, neoadjuvant chemotherapy followed by surgery is the standard for operable N2-disease, except for superior sulcus tumors, where neoadjuvant chemo-radiotherapy remains the standard of care (4). "Resectability" is based on the definition by the IASLC (International Association for the Study of Lung Cancer), which is implemented in all recent SAKK trial protocols (5). At our institution, we define resectability upfront, to avoid R1-2 resections in any patient with NSCLC. Outside of a clinical trial, we do not perform induction chemotherapy to "convert" unresectable tumors for surgery, because this concept was never proven to be effective in larger trials.

What do we do in persistent N2 disease? In our view, in the case of nonresponding, radiologically stable disease after chemotherapy, surgery is still an option, if the patient is fit, if lobectomy can be performed, and if there is no bulky or multi-level mediastinal involvement. We avoid (rightsided) pneumonectomy, because of increased morbidity and mortality (6). Based on the pathological analysis of 
the resection specimen, and the postoperative condition of the patient, postoperative radiotherapy (PORT) should be discussed at the multidisciplinary tumor board, although the evidence supporting PORT is retrospective, as the results of the randomized LungART trial are pending (7). If the tumor progresses and becomes unresectable during chemotherapy, we dismiss surgery and switch to definitive chemo-radiotherapy. Before chemo-radiotherapy, we repeat PET-CT and brain MRI to rule our distant metastases. After chemo-radiotherapy, we do not use consolidation chemotherapy, but we routinely add consolidation immunotherapy, based on the results of the PACIFIC trial $(8,9)$. In metastatic disease, optimal choice of further lines of systemic therapy will depend on molecular markers, which we test already at the time of initial diagnosis in stage III (and IV) nowadays.

What will the future bring? Relevant advances can be expected from neoadjuvant use of immune checkpoint inhibitors plus chemotherapy, a combination which is already very successful for the treatment of patients with metastatic NSCLC. In 2019, preliminary results in N2 disease were presented from the Spanish nonrandomized phase II trial NADIM. Patients with N2 or T4 N0 disease were treated with 3 cycles of nivolumab, paclitaxel and carboplatin. Among the first 41 operated patients, $83 \%$ had a major pathological response (MPR) and $59 \%$ had complete pathologic response, which is truly remarkable (10). Another trial recruited 30 patients with operable NSCLC, including 23 patients with stage IIIA, using neoadjuvant therapy with 2-4 cycles of atezolizumab, paclitaxel and carboplatin (11). Twenty-nine (97\%) patients had surgery, 26 (87\%) had R0 resection, and 57\% had MPR. First results from the SAKK16/14 trial were released as an abstract (12). Sixty-eight patients with resectable N2 disease received 3 cycles of cisplatin and docetaxel, followed by 2 cycles of durvalumab. Fifty-five (81\%) patients had surgery, the main reason for not undergoing surgery was disease progression. Radiologic response rate was 59\%, EFS after 1 year was $73 \%$. Further data, including pathological response rate, will be reported at the ASCO 2020 meeting. A new trial SAKK16/19 is ongoing, to study the role of low-dose radiotherapy as an immunosensitizer during neoadjuvant immuno-chemotherapy.

Perioperative immunotherapy remains work in progress. Safety needs to be addressed by randomized trials, although preliminary data from clinical trials do not suggest increased mortality or morbidity. The predictive value of pathological response for long-term survival needs to be validated. The hypothetical superiority of neoadjuvant immunotherapy over adjuvant immunotherapy warrants confirmation. Once the clinical benefit is fully established, the cost-efficacy of a short course of neoadjuvant immunotherapy will need to be compared with adjuvant immunotherapy for up to 1 year. Challenges will remain in the treatment of tumors progressing under neoadjuvant immunotherapy. Surgical trials provide laboratories with sufficient material, to get new insights into the biology of tumor escape mechanisms. These efforts will ultimately improve immunotherapy for NSCLC of all stages. Enrolment of patients into clinical trials therefore remains highly important.

\section{Acknowledgments}

Funding: None.

\section{Footnote}

Provenance and Peer Review: This article was commissioned by the editorial office, Current Challenges in Thoracic Surgery for the series "Controversies in the Management of Stage IIIA Non-Small-Cell Lung Cancer". The article has undergone external peer review.

Peer Review File: Available at https://ccts.amegroups.com/ article/view/10.21037/ccts-20-87/prf

Conflicts of Interest: All authors have completed the ICMJE uniform disclosure form (available at https://ccts. amegroups.com/article/view/10.21037/ccts-20-87/coif). The series "Controversies in the Management of Stage IIIA Non-Small-Cell Lung Cancer" was commissioned by the editorial office without any funding or sponsorship. FM served as the unpaid Guest Editor of the series. OG is a consultant for AMGEN, during the conduct of the study. The authors have no other conflicts of interest to declare.

Ethical Statement: The authors are accountable for all aspects of the work in ensuring that questions related to the accuracy or integrity of any part of the work are appropriately investigated and resolved.

Open Access Statement: This is an Open Access article distributed in accordance with the Creative Commons Attribution-NonCommercial-NoDerivs 4.0 International License (CC BY-NC-ND 4.0), which permits the noncommercial replication and distribution of the article with 
the strict proviso that no changes or edits are made and the original work is properly cited (including links to both the formal publication through the relevant DOI and the license). See: https://creativecommons.org/licenses/by-nc-nd/4.0/.

\section{References}

1. Betticher DC, Hsu Schmitz SF, Tötsch M, et al. Mediastinal lymph node clearance after docetaxel-cisplatin neoadjuvant chemotherapy is prognostic of survival in patients with stage IIIA pN2 non-small-cell lung cancer: a multicenter phase II trial. J Clin Oncol 2003;21:1752-9.

2. Pless M, Stupp R, Ris HB, et al. Induction chemoradiation in stage IIIA/N2 non-small-cell lung cancer: a phase 3 randomised trial. Lancet 2015;386:1049-56.

3. Früh M, Betticher DC, Stupp R, et al. Swiss Group for Clinical Cancer Research (SAKK). Multimodal Treatment in Operable Stage III NSCLC: A Pooled Analysis on Long-Term Results of Three SAKK trials (SAKK 16/96, 16/00, and 16/01). J Thorac Oncol 2019;14:115-23.

4. Rusch VW, Giroux DJ, Kraut MJ, et al. Induction chemoradiation and surgical resection for superior sulcus non-small-cell lung carcinomas: long-term results of Southwest Oncology Group Trial 9416 (Intergroup Trial 0160). J Clin Oncol 2007;25:313-8.

5. Porta R, Wittekind C, Goldstraw P; International Association for the Study of Lung Cancer (IASLC) Staging Committee. Complete resection in lung cancer surgery: proposed definition. Lung Cancer 2005;49:25-33.

6. Albain KS, Rusch VW, Swann RS, et al. Radiotherapy plus

doi: $10.21037 /$ ccts-20-87

Cite this article as: Gautschi O, Minervini F, Kestenholz P. Persistent N2 disease after neoadjuvant treatment...and now? -The oncologist view. Curr Chall Thorac Surg 2021;3:43. chemotherapy with or without surgical resection for stage III non-small cell lung cancer: a phase III randomizsed controlled trial. Lancet 2009;374:379-86.

7. Zeng WQ, Feng W, Xie L, et al. Postoperative Radiotherapy for Resected Stage IIIA-N2 Non-small-cell Lung Cancer: A Population-Based Time-Trend Study. Lung 2019;197:741-51.

8. Antonia SJ, Villegas A, Daniel D, et al. Overall Survival with Durvalumab after Chemoradiotherapy in Stage III NSCLC. N Engl J Med 2018;379:2342-50.

9. Ahn JS, Ahn YC, Kim JH, et al. Multinational Randomized Phase III Trial With or Without Consolidation Chemotherapy Using Docetaxel and Cisplatin After Concurrent Chemoradiation in Inoperable Stage III NonSmall Cell Lung Cancer: KSCG-LU05-04. J Clin Oncol 2015;33:2661-71.

10. Provencio M, Nadal M, Insa A, et al. NADIM Study: Updated Clinical Research and Outcomes. J Thorac Oncol 2019;14:S241.

11. Shu CA, Gainor JF, Awad MM, et al. Neoadjuvant atezolizumab and chemotherapy in patients with resectable non-small-cell lung cancer: an open-label, multicentre, single-arm, phase 2 trial. Lancet Oncol 2020;21:786-95.

12. Rothschild S, Zippelius A, Savic S, et al. SAKK 16/14: Anti-PD-L1 antibody durvalumab in addition to neoadjuvant chemotherapy in patients with stage IIIA(N2) non-small cell lung cancer (NSCLC)-A multicenter single-arm phase II trial. J Clin Oncol 2020. doi: 10.1200/ JCO.2018.36.15_suppl.TPS8584 